\title{
Sodium-lithium countertransport in children with diabetes and their families
}

\author{
P N Houtman, F M Campbell, V Shah, D B Grant, D B Dunger, M J Dillon
}

\begin{abstract}
Abnormalities of sodium-lithium countertransport have been extensively implicated in adult primary hypertension and $a$ relationship between sodium-lithium countertransport and family history of hypertension in children has been previously found. More recently it has been suggested that increased sodium-lithium countertransport may play a part in the pathogenesis of nephropathy in insulin dependent diabetes mellitus (IDDM). Children and adolescents with IDDM and their family members were studied. In those with IDDM $(n=36$, median age 14.6 years, range $9 \cdot 5-19 \cdot 2$ years) there was no relationship between sodium-lithium countertransport (range 0.098-0.585 mmol/1 red blood cells/hour) and age, blood pressure as expressed by systolic or diastolic SD scores, glycated haemoglobin, serum lipids, or intracellular sodium concentration. A positive relationship $\left(r_{\mathrm{s}}=0.44\right)$ was found between sodiumlithium countertransport and early morning urinary albumin to urinary creatinine ratio (UA/UC), expressed as the logarithm of the geometric mean of two consecutive samples, for each individual (range 0.4-22 $\mathrm{mg} / \mathrm{mmol}$ ). Sodium-lithium countertransport was increased in those with IDDM compared with their non-diabetic siblings, in a paired analysis $(n=26)$. There was no relationship between UAVUC in the children with diabetes and sodium-lithium countertransport in their parents. These studies in this population of diabetic children indicate that increased sodiumlithium countertransport may play a part in the early stages of the development of nephropathy in IDDM.

(Arch Dis Child 1995; 72: 133-136)
\end{abstract}

Keywords: sodium-lithium countertransport, diabetes, nephropathy, microalbuminuria.

Department of Paediatric Nephrology, Institute of Child Health, London P N Houtman F M Campbel V Shah

D B Grant

M J Dillon

Department of Paediatrics, John Radcliffe Hospital, Oxford

D B Dunger

Correspondence to: Dr P N Houtman, Leicester Royal Infirmary Children's Hospital, Leicester LE1 5WW.

Accepted 12 October 1994 shown that the frequency of nephropathy in diabetic siblings of diabetic probands with nephropathy is considerably higher than that in diabetic siblings of diabetic probands without nephropathy. ${ }^{45}$

Hypertension is an interacting factor in determining susceptibility to diabetic nephropathy. ${ }^{26}$ Sodium-lithium countertransport activity in red blood cells, known for some time to be a marker of risk for essential hypertension, ${ }^{7-9}$ has more recently come to be associated with diabetic nephropathy. Sodiumlithium countertransport has been found to be increased in those diabetics with established nephropathy ${ }^{1011}$ or microalbuminuria, ${ }^{12}$ and this increased activity has also been found in their parents. ${ }^{13}$

Overt renal disease is unusual in young people with IDDM, but the propensity to develop later manifestations may be studied using urinary albumin excretion as an early marker of nephropathy. ${ }^{14}$ The main aim of the present study was to determine whether it was possible to show an association between sodium-lithium countertransport and urinary albumin excretion, when measured at an early age, and to show any relationships with countertransport in family members.

\section{Patients and methods}

Thirty six patients with IDDM were recruited from those attending the paediatric diabetic clinic at the John Radcliffe Hospital, Oxford and the Hospital for Sick Children, Great Ormond Street, London. Parents and siblings also agreed to take part in the study. Sixteen of these patients were about to undergo a study to assess changes in proteinuria with treatment, and were therefore selected from a larger group for the presence of microalbuminuria. All patients and parents were of European origin, and none of the patients were on any medication apart from insulin treatment. There was no evidence of overt renal or cardiovascular disease in any patient. However, two parents were on drug treatment for hypertension.

Urine albumin excretion was determined using the urinary albumin to urinary creatinine ratio (UA/UC) and expressed as the geometric mean of two consecutive early morning urine samples. Urinary albumin was measured by radioimmunoassay and urinary creatinine by the Jaffe reaction.

The method used for sodium-lithium countertransport was similar to that of Canessa et $\mathrm{al}^{7}$ incorporating some modifications as reported by Rutherford et al. ${ }^{15}$ Further modifications in our assay were necessary in view of the smaller quantities of blood available from young children and the concomitant need for greater precision. Venous blood, minimum $5 \mathrm{ml}$, was collected into tubes containing 
lithium heparin, centrifuged, and the erythrocytes incubated in lithium loading solution (140 mmol lithium chloride, $10 \mathrm{mmol} / \mathrm{l}$ lithium carbonate, $10 \mathrm{~mm} / 1$ glucose, $10 \mathrm{mmol} / \mathrm{l}$ Tris-acetate, gassed with $95 \%$ oxygen $/ 5 \%$ carbon dioxide, $\mathrm{pH} 7 \cdot 5,290 \mathrm{mosmol} / \mathrm{kg}$ ) for 90 minutes at $37^{\circ} \mathrm{C}$. The erythrocytes were then washed once with magnesium chloride $\left(\mathrm{MgCl}_{2}\right) \quad(290 \mathrm{mosmol} / \mathrm{kg})$ and twice with choline medium (139 mmol/1 choline chloride, $1 \mathrm{mmol} / 1 \mathrm{MgCl}_{2}, 10 \mathrm{mmol} / 1$ glucose, $10 \mathrm{mmol} / \mathrm{l}$ Tris-acetate, $\mathrm{pH} 7 \cdot 4,290 \mathrm{mosmol} / \mathrm{kg}$ ). After the final washing $0.05 \mathrm{ml}$ portions of erythrocytes were incubated at $37^{\circ} \mathrm{C}$ in four tubes containing $0.6 \mathrm{ml}$ of choline medium (as above) including $10^{-4} \mathrm{~mol} / \mathrm{l}$ ouabain and four tubes containing $0.6 \mathrm{ml}$ of sodium medium (145 mmol/1 sodium chloride, $1 \mathrm{mmol} / \mathrm{l}$ $\mathrm{MgCl}_{2}, 10 \mathrm{mmol} / 1$ glucose, $10 \mathrm{mmol} / 1$ Trisacetate, $10^{-4} \mathrm{~mol} / \mathrm{l}$ ouabain, $\mathrm{pH} 7 \cdot 4,290$ mosmol/ $/ \mathrm{kg}$ ). The packed cell volume of the erythrocytes was $0.80 \pm 0.03$ and this figure was used in further calculations. The tubes were cooled after $30,60,90$, and 120 minutes for both sodium and choline-containing media, and centrifuged at $2000 \mathrm{~g}$ for 5 minutes. An aliquot of $200 \mu$ l supernatant was mixed with $2.075 \mathrm{ml}$ of $1.63 \mathrm{mmol} / 1$ caesium chloride in duplicate tubes and the lithium content was measured using an IL 943 flame photometer (Instrumentation Laboratory). The analyst undertaking this determination was unaware of the identity of the subject. The sodium-lithium countertransport activity (mmol lithium/l red blood cells/hour) was determined as the difference between lithium efflux from erythrocytes in the sodium and choline media. The between assay coefficient of variation using this technique for countertransport was $11 \%$, and to maintain validity a control sample was assayed in parallel during each experimental run.

Blood pressure was recorded using a random zero mercury sphygmomanometer, with the subject resting in the sitting position. Three readings were taken and the average measurements of systolic and diastolic (Korotkov sound IV) blood pressures used. Family history of high blood pressure was recorded from the parents of the children in the study. A ranked score was derived from this information using a five tiered scale as previously described. ${ }^{16}$

Analyses between means of groups were by unpaired $t$ tests. Parametric regression was used for comparisons except those involving family history score and body mass index for which a non-parametric statistic was obtained (Spearman's coefficient).

The study was approved by the ethics committee of the Hospital for Sick Children and Institute of Child Health, London and the Oxford district ethical committee.

Primary details of the study groups

\begin{tabular}{llll}
\hline & $\begin{array}{l}\text { Diabetics } \\
(n=36)\end{array}$ & $\begin{array}{l}\text { Siblings } \\
(n=35)\end{array}$ & $\begin{array}{l}\text { Parents } \\
(n=54)\end{array}$ \\
\hline M:F & $14: 22$ & $16: 19$ & $27: 27$ \\
Median age (range) & $14 \cdot 6(9-19)$ & $13 \cdot 2(5-21)$ & $43(32-59)$
\end{tabular}

\section{Results}

Primary details of the patients, their parents, and their non-diabetic siblings are shown in the table.

In 27 families both parents were studied, and only these families were used for analyses involving parents. Siblings were available in 26 families, and when more than one non-diabetic sibling from a family was studied, their mean sodium-lithium countertransport was used.

In the diabetic patients the sodium-lithium countertransport activity in the red blood cells ranged from 0.06 to $0.58 \mathrm{mmol}$ lithium $/ \mathrm{l}$ red blood cells/hour (mean 0.33 ). There was no relationship between sodium-lithium countertransport and age, duration of diabetes, blood pressure as expressed by systolic or diastolic SD scores, glycated haemoglobin, serum lipids, or intracellular sodium concentration, in these patients. No significant relationship was found with body mass index (mean $21 \cdot 2 \mathrm{~kg} / \mathrm{m}^{2}$, range 14-33). There was also no relationship found between sodium-lithium countertransport and family history score for hypertension.

In the non-diabetic siblings of the diabetics, sodium-lithium countertransport ranged from 0.08 to $0.53 \mathrm{mmol}$ lithium $/ 1$ red blood cells $/$ hour (mean 0.27 ). In a paired analysis, sodiumlithium countertransport in the diabetics was significantly higher than that in the non-diabetic siblings $(n=26, p=0.025)$. There was no difference in age between these two groups.

Mean UA/UC ranged from 0.3 to 22 $\mathrm{mg} / \mathrm{mmol}$ in the diabetics. There was a positive correlation between sodium-lithium countertransport and mean UA/UC (log adjusted to account for distribution $)^{17}\left(n=36, r_{s}=0.44\right.$, $\mathrm{p}=0.01$; figure), not accounted for by age or body mass index in multiple regression.

In the parents sodium-lithium countertransport ranged from 0.11 to $0.62 \mathrm{mmol}$ lithium/1 red blood cells/hour (mean maternal 0.28 and mean paternal 0.35 ). Using both mid-parental and the higher of parental sodium-lithium countertransport values, there was no relationship between parental sodium-lithium countertransport and UA/UC in their diabetic children $(n=27)$.

\section{Discussion}

Cell membrane transport has been linked to both hypertension and diabetic nephropathy

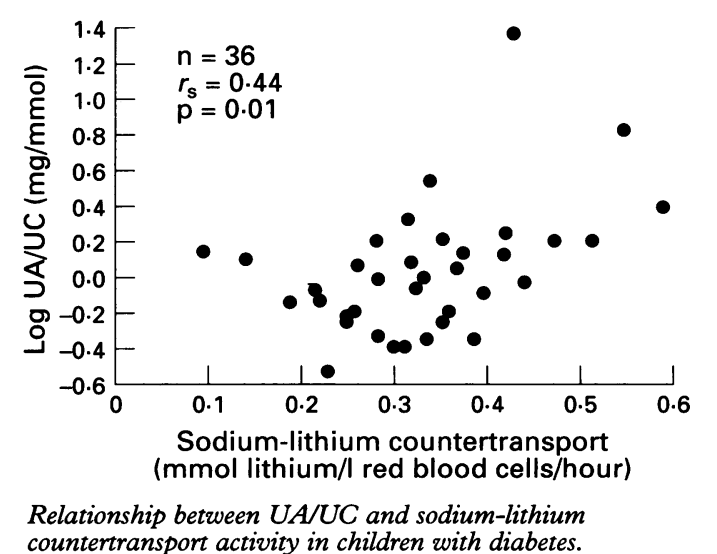


for some time. Much more difficult has been the task of determining precise links between susceptibility to disease and genetic variability in these cell membrane transport systems. It is with sodium-lithium countertransport that the strongest links have been established, ${ }^{18-20}$ and we believe that there are distinct advantages to studying this system at an early age.

One of the main aims of such research is to predict the secondary complications of disease, such as diabetic nephropathy. We chose UAVUC as a continuous variable because there is increasing evidence that not only is urinary albumin excretion a good predictor of later nephropathy and cardiovascular disease, ${ }^{12}$ but also that even very low degrees of microalbuminuria are significant in terms of later renal and cardiovascular complications. ${ }^{21} 22$ This approach allowed us to use a young diabetic population with little overt evidence of any renal damage, but precisely the sort of population which would benefit most from disease prevention. Thus our main finding concerns the positive relationship between sodium-lithium countertransport and urinary albumin excretion in children and adolescents with diabetes. This finding has previously been seen in adults, ${ }^{12}$ but the importance of this relationship being discernible so early in the course of the diabetes lies in its significance regarding genetic susceptibility to diabetic complications.

Another reason which makes it a distinct advantage to study a young population is in terms of the potentially reduced influence of the long term secondary effects of morbidity. For example, it has been difficult in this area of research to disentangle the influence of blood pressure on susceptibility to diabetic nephropathy. This area is, in fact, now quite complex, and it is considered that sodiumlithium countertransport is important in both hypertension and diabetic nephropathy, but in different ways according to differing kinetic changes in the transport system. ${ }^{23-25}$ These factors do not concern us directly, and children rarely manifest essential hypertension. Whereas it has been possible to find a relationship between sodium-lithium countertransport and family history of hypertension at a very early age, ${ }^{16}$ we would not expect actual variability in blood pressure at this age to be perceptible in terms of any relationships with disease variables. Therefore we were not surprised that we did not find relationships between sodium-lithium countertransport and systolic and diastolic blood pressure scores, or indeed with serum lipids or glycated haemoglobin concentrations. It may have been more likely to have found a relationship with family history of hypertension in our diabetic population. However, our previous work in this area had involved a larger screening pool. A similar argument applies to body mass index, known to be associated with sodium-lithium countertransport, ${ }^{26}$ but our negative results may also be concerned with the confounding effects of diabetes on body habitus.

We failed to find a relationship between microalbuminuria in the children and their parents' countertransport. Using older populations such relationships have been found, ${ }^{13}$ and so it was integral to our study to measure countertransport in the family members. Our failure to define a relationship is likely to be related to the youth of the diabetic patients rather than the youth of their parents. Whereas variability in sodium-lithium countertransport activity is thought to be largely genetically determined, ${ }^{27}$ microalbuminuria would be expected to be slowly evolving in the early years of diabetes so that any genetic influence from parents would be unlikely to be sufficiently defined in a marker such as urinary albumin to creatinine concentration.

We found that sodium-lithium countertransport in the diabetic patients was greater than that in their non-diabetic siblings. This has not been a common finding in the literature $^{28}$ and appears to implicate sodium-lithium countertransport in the diabetic process itself as well as being part of the propensity to develop complications. ${ }^{29}$ Sodium-lithium countertransport is known to be affected by lipids, ${ }^{30}$ glucose, ${ }^{31}$ and insulin concentrations, ${ }^{24}$ but only to a small extent in clinical practice, and it would be unlikely that this would account for our finding. Rather it may be that sodium-lithium countertransport is involved in diabetic propensity, and that this difference between diabetic children and their healthy siblings is more likely to be discernible at this early age than later, before other complicating factors muddle any delineation.

In summary we have found that microalbuminuria is associated with increased sodium-lithium countertransport in young diabetic children, before the onset of overt nephropathy. Countertransport was higher in diabetics than their non-diabetic siblings, but we found no relationship between parental countertransport and diabetic albumin excretion. These studies are further evidence of a relationship between cell membrane transport and diabetic nephropathy that can be found at an early age.

We thank Dr G Sagnella of St George's Hospital Medical School, and Dr T Thomas and Profes... R Wilkinson of the Freeman Hospital, Newcastle upon Tyne for their technical advice and support.

This work was supported by the Charlotte Parkinson Research

This work was supported by the Charlotte Parkinson Research Research Appeal Trust), and the Kidney Research Aid Fund.

1 Viberti GC, Walker JD. Diabetic nephropathy: etiology and prevention. Diabetes Metab Rev 1988; 4: 147-62.

2 Viberti GC, Messent J. Risk factors for renal and cardiovascular disease in diabetic patients. Cardiology 1991; 79 (suppl): 55-61.

3 Krolewski AS, Warram JH, Christlieb AR, Busick EJ, Kahn CR. The changing natural history of nephropathy in type 1 diabetes. Am ₹ Med 1985; 78: 785-94.

4 Seaquist ER, Goetz FC. Familial clustering of diabetic kidney disease. Evidence for genetic susceptibility to diabetic nephropathy. N Engl f Med 1989; 320: 1161-5.

5 Borch Johnsen K, Norgaard K, Hommel E, et al. Is diabetic nephropathy an inherited complication? Kidney Int 1992; 41: $719-22$.

6 Barzilay J, Warram JH, Bak M, Laffel LM, Canessa M, Krolewski AS. Predisposition to hypertension: risk factor for nephropathy and hypertension in IDDM. Kidney Int for nephropathy a

7 Canessa M, Adragna N, Solomon HS, Connolly TM Tosteson DC. Increased sodium/lithium countertransport in red cells of patients with essential hypertension. $N E n g l$ in red cells of patients

8 Williams RR, Hunt SC, Kuida H, Smith JB, Ash KO Sodium-lithium countertransport in erythrocytes of hypertension prone families in Utah. Am $\mathcal{f}$ Epidemio 1983; 118: 338-44. 
9 Carr SJ, Thomas TH, Wilkinson R. Erythrocyte sodiumlithium countertransport in primary and renal hypertension: relation to family history. Eur $\mathcal{f}$ Clin Invest 1989; 19: sion: re $101-6$.

10 Krolewski AS, Canessa M, Warram JH, et al. Predisposition to hypertension and susceptibility to renal disease in
insulin-dependent diabetes mellitus. $N$ Engl $\mathcal{F}$ Med 1988; 318: 140-5.

11 Mangili R, Bending J, Scott G, Li LK, Gupta A, Viberti G. Increased sodium-lithium countertransport activity in red cells of patients with insulin-dependent diabetes and nephropathy. N Engl f Med 1988; 318: 146-50.

12 Jones SL, Trevisan R, Tariq T, et al. Sodium-lithium countertransport in microalbuminuric insulin-dependent diabetic patients. Hypertension 1990; 15: 570-5.

13 Walker JD, Tariq T, Viberti G. Sodium-lithium countertransport activity in red cells of patients with insulin dependent diabetes and nephropathy and their parents [see comments]. BMF 1990; 301: 635-8.

14 Mogensen CE. Natural history of renal functional abnormalities in human diabetes mellitus: from normoalbuminuria to incipient and overt nephropathy. In: Brenner BM, Stein JH, eds. Contemporary issues in nephrol Brenner BM, Stein JH, eds. Contemporary issues in nephrology: the kidney in diabetes

15 Rutherford PA, Thomas TH, Wilkinson R. Increased erythrocyte sodium-lithium countertransport activity in essential hypertension is due to an increased affinity for extracellular sodium. Clin Sci 1990; 79: 365-9.

16 Houtman PN, Shah V, Dillon MJ. Sodium-lithium countertransport and family history of hypertension in childhood. Acta Paediatr 1993; 82: 1057-60.

17 Gibb DM, Shah V, Preece M, Barratt TM. Variability of urine albumin excretion in normal and diabetic children. Pediatr Nephrol 1989; 3: 414-9.

18 Weder AB. Cation transport markers as predictors of hypertension. Am $\mathcal{F}$ Hypertens 1991; 4: S633-7.

19 Rutherford PA, Thomas TH, Wilkinson R. Erythrocyte sodium-lithium countertransport: clinically useful, pathophysiologically instructive or just phenomenology? physiologically instructive or just

20 Swales JD. Functional disturbance of the cell membrane in hypertension. $\mathcal{F}$ Hypertens 1990; 8: S203-11.
21 Gibb DM, Dunger DB, Levin M, Shah V, Smith C, Barratt TM. Early markers of the renal complications of insulindependent diabetres mellitus. Arch Dis Child 1989; 64: 984-91.

22 Messent J, Elliott TG, Hill RD, Jarrett RJ, Keen H, Viberti GC. Prognostic significance of microalbuminuria in insulin-dependent diabetes mellitus:

23 Rutherford PA, Thomas TH, Wilkinson R. Increased erythrocyte sodium-lithium countertransport activity in essential hypertension is due to an increased affinity for extracellular sodium. Clin Sci 1990; 79: 365-9.

24 Canessa M, Zerbini G, Laffel LM. Sodium activation kinetics of red blood cell $\mathrm{Na}+/ \mathrm{Li}+$ countertransport in diabetes: methodology and controversy. $f \mathrm{Am}$ Soc Nephrol 1992; 3: S41-9.

25 Rutherford PA, Thomas TH, Carr SJ, Taylor R, Wilkinson $R$. Changes in erythrocyte sodium-lithium countertransport kinetics in diabetic nephropathy. Clin $S_{c i} 1992 ; 82$ : 301-7.

26 Weder AB, Schork NJ, Krause L, Julius S. Red blood cell lithium-sodium countertransport in the Tecumseh blood pressure study. Hypertension 1991; 17: 652-60.

27 Hasstedt SJ, Wu LL, Ash KO, Kuida H, Williams RR. Hypertension and sodium-lithium countertransport in Utah pedigrees: evidence for majo

28 Hardman TC, Dubrey SW, Leslie DG, Hafiz M, Noble MI, Lant AF. Erythrocyte sodium-lithium countertransport and blood pressure in identical twin pairs discordant for insulin dependent diabetes. $B M \mathcal{F}$ 1992; 305: 215-9.

29 Elving LD, Wetzels JF, De Pont Jj, Berden JH. Is increased erythrocyte sodium-lithium countertransport a useful marker for diabetic nephropathy? Kidney Int 1992; 41: 862-71.

30 Rutherford PA, Thomas TH, Carr SJ, Taylor R, Wilkinson R. Kinetics of sodium-lithium countertransport activity in 1992; 82: 291-9.

31 Mattiasson I, Berntorp K, Kindgarde F. Sodium-lithium countertransport and platelet cytosolic free calcium concountertransport and platelet cytosolic free calcium conpostmenopausal women. Clin Sci 1992; 83: 319-24. 